\title{
Soft Tissue and Bone Reconstruction in Severe Open Fractures of the Lower Extremity
}

There was a time when an open fracture was synonymous with amputation. Young Blakeney had his right arm amputated in the sea battle between the the British ship HMS Surprise and the French ship Acheron in the Napoleonic Wars in the nineteenth century in Peter Weir's film Master and Commander [1]. Since the time of Napoleon, a lot of progress has been achieved in this field due to medical and surgical (r)evolutions, such as the introduction of the external fixator at the beginning of the twentieth century [2]. In 1992 we still asked "external fixator, what next?" [3], and presented options for the conversion from external to internal fixation. Today external fixation is less popular; unreamed nailing procedures and bridging plate procedures using angle-stable implants are favored, even in severe situations such as high-degree open fractures [4], provided that accurate repeat debridement and early soft tissue coverage is respected [5]. However, the reconstruction of large (post-)traumatic diaphyseal bone defects remains a special surgical challenge.

On the other hand, the use of flaps for soft tissue reconstruction was described as far back as the beginning of the twentieth century, but according to Raoul Tubiana, the real stimulus for reconstructive surgery was the introduction of microvascular techniques [6]. Today there are a wide variety of flaps that can be used to perform early coverage of soft tissue defects in the presence of open fractures.

Early flap construction is not feasible in all cases; sometimes local conditioning is mandatory in order to prepare the wound for secondary procedures such as split skin grafting. Introduced in 1990, the vacuum sealing technique - today simply called VAC - has been used in such circumstances and has also gained widespread use in the treatment of open fractures [7], although its exact mechanism of action is still a subject for discussion, and its effect is still occasionally contested, even today [8]. VAC continues to be an useful adjunct in the treatment of severe soft tissue damage in the presence of open fractures [9].

It is the aim of this edition to focus on these recent developments in the treatment of severe open fractures

Eur J Trauma Emerg Surg 2009;35:1

DOI 10.1007/s00068-008-9001-0

Published Online: January 17, 2009 and sequelae. Surgical options are described, the advantages and disadvantages of such surgical procedures are discussed, and therapeutic strategies are presented.

However, these options are not real or realistic solutions for such limb- and sometimes life-threatening situations in all parts of the world. Thus, it is useful and also appropriate for us - as residents of technologically advanced First World countries - to consider the different conditions that prevail in the Third World, where free flaps may not be performed for logistic reasons. While a lot can be achieved by simple local flaps, amputation is still an option that should be discussed. The nineteenth century may have gone, but some areas of the world are yet to enter the twenty-first century as we know it; sometimes young Blakeney is still among us.

\section{Dominik Heim \\ Society Liaison Editor}

\section{References}

1. Weir P (screenplay, director), Collee J (screenplay). Master and Commander: the far side of the world (film). Los Angeles: Twentieth Century-Fox et al., 2003 (including Max Pirkis as Blakeney).

2. Lambotte A. L'intervention opératoire dans les fractures. Brussels: Lamartin, 1907.

3. Heim D, Regazzoni P, Perren SM. Current use of external fixation in open fractures (external fixator: what next?). Injury Suppl 1992;23.

4. Ueno M, Yokoyama K, Nakamura K, et al. Early unreamed intramedullary nailing without a safety interval and simultaneous flap coverage following external fixation in type IIIB open tibial fractures: a report of four successful cases. Injury Int J Care Injured 2006;37:289-94.

5. Kakar S, Tornetta P III. Open fractures of the tibia treated by immediate intramedullary tibial nail insertion without reaming: a prospective study. J Orthop Trauma 2007;21:153-7.

6. Masquelet AC, Gilbert A. An atlas of flaps in limb reconstruction. London: Martin Dunitz, 1995.

7. Fleischmann W, Strecker W, Bombelli M, Kinzl L. Vaccum sealing as treatment of soft tissue damage in open fractures. Unfallchirurg 1993;96:488-92.

8. Ubbink DT, Westerbos SJ, Nelson EA, Vermeulen H. A systematic review of topical negative pressure therapy for acute and chronic wounds. Br J Surg 2008;95:685-92.

9. Dedmond BT, Kortesis B, Punger K, et al. The use of negativepressure wound therapy in the temporary treatment of softtissue injuries associated with high-energy open tibial shaft fractures. J Orthop Trauma 2007;21:11-7. 